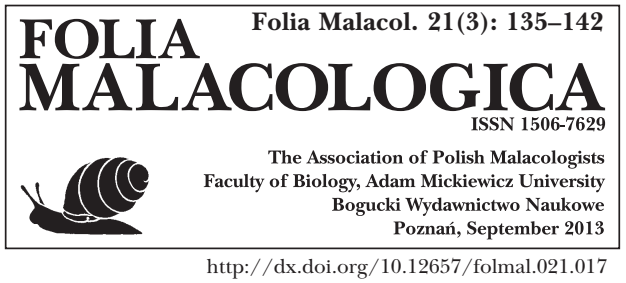

\title{
VINODOLIA FIUMANA RADOMAN, 1973 (CAENOGASTROPODA: RISSOOIDEA): REDISCOVERY AND RELATIONSHIPS OF A SPECIES PRESUMED EXTINCT
}

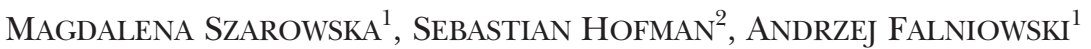 \\ ${ }^{1}$ Department of Malacology, Institute of Zoology, Jagiellonian University, Gronostajowa 9, 30-387 Cracow, \\ Poland (e-mail: magdalena.szarowska@uj.edu.pl; andrzej.falniowski@uj.edu.pl) \\ ${ }^{2}$ Department of Comparative Anatomy, Institute of Zoology, Jagiellonian University, Gronostajowa 9, 30-387 \\ Cracow, Poland
}

\begin{abstract}
Vinodolia fiumana was described by Radoman from Glogi spring in 1973, and later not found, thus considered extinct. In the CLECOM list Anagastina, Dalmatinella and Prespiana were classified, as subgenera, within the genus Vinodolia. After visiting the Glogi spring on several occasions, we found four specimens of $V$. fiumana. Its shell, soft part external morphology, radula, penis and female reproductive organs are described. Partial cytochrome oxidase subunit I mitochondrial and 18S rRNA nuclear gene sequences were used to infer phylogenetic relationships of Vinodolia. Sadleriana was found to be the sister taxon of Vinodolia, but neither Anagastina (closely related with Radomaniola), nor Dalmatinella were closely related with it.
\end{abstract}

KEY WORDS: Rissooidea, COI, 18S rRNA, radula, anatomy, extinction, phylogeny

\section{INTRODUCTION}

The monotypic genus Vinodolia, with the type species V. fiumana Radoman, 1973, was described by RADOMAN (1973) from the Glogi spring at Bribir, northern Croatia. He reported this species also from the Drišs spring, close to Glogi and from the spring in the Javor village, N of Martinščica, E of Rijeka (RADOMAN 1973, 1974, 1983). To our knowledge, nobody has found this species since, and RÉGNIER et al. (2009) listed it among extinct species. Despite very fragmentary information and without any explanation, Anagastina Radoman, 1978, Dalmatinella Radoman, 1973, and Prespiana Radoman, 1973, are considered subgenera of Vinodolia in both the CLECOM list (FALKNER et al. 2001), and in Fauna Europaea (BANK 2012).

We visited the Glogi spring a few times, from 1999 to 2004, only to find the spring almost dry, and nothing more than a few corroded empty shells of an unidentified rissooid snail in the bottom sediments. Finally, in June of 2011, we found four specimens of $V$. fiumana. The aim of the present study was to check the morphology of the species, and to infer phylogenetic relationships with molecular data.

\section{MATERIAL AND METHODS}

Four specimens and a few corroded empty shells of Vinodolia fiumana were collected, using a sieve (two meshes per mm), from Glogi Spring at Bribir (Fig. 1): $45^{\circ} 10^{\prime} 02.1^{\prime \prime N}, 14^{\circ} 44^{\prime} 25.6^{\prime \prime E}, 154 \mathrm{~m}$ a.s.l., on June 15th, 2011. There was no outflow outside the spring, only a little water inside the small artificial pool.

Snails were washed twice in $80 \%$ ethanol and left to stand in it for around 12 hours. Then the ethanol was changed twice more within 24 hours and finally, 


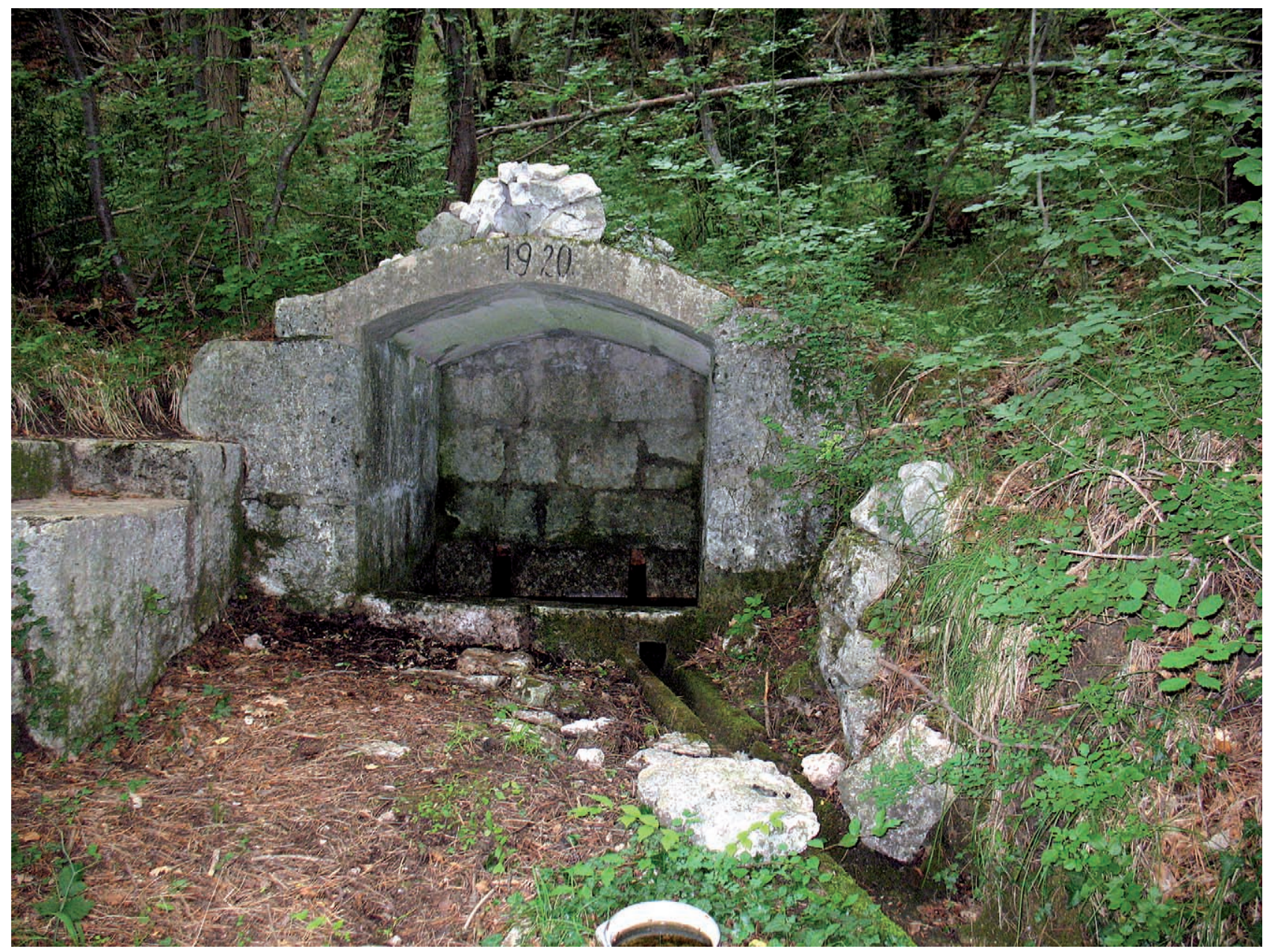

Fig. 1. Glogi Spring at Bribir, type locality of Vinodolia fiumana

after a few days, the $80 \%$ solution was replaced with a $96 \%$ one, in which the samples were stored at $-20^{\circ} \mathrm{C}$. The shells were photographed with a CANON EOS $50 \mathrm{D}$ digital camera. One adult male and one female were dissected, using a NIKON SMZ-U stereoscope microscope. The penis and female genitalia (pallial oviduct) were examined using a MOTIC light microscope. The radula of the female was examined using a JEOL JSM-5410 scanning electron microscope, applying the techniques described by FALNIOWSKI (1990).

DNA was extracted from foot tissue of the fourth specimen not presented in the photograph. The tissue was hydrated in TE buffer $(3 \times 10 \mathrm{~min}$. $)$; then total genomic DNA was extracted with the SHERLOCK extracting kit (A\&A Biotechnology), and the final product was dissolved in $20 \mu \mathrm{l} \mathrm{TE}$ buffer. The PCR reaction was performed with the following primers: LCO1490 ( 5 '-GGTCAA CAAAT CATAAAGATATT GG-3') (FOLMER et al. 1994) and COR722b (5'-TAAACTTCA GGGTGACCAAAAAATYA-3') (WILKE \& DAVIS 2000) for the cytochrome oxidase subunit I (COI) mitochondrial gene and SWAM18SF1 (5'-GAATGGCTCAT TAAATCAGTCGAGGTTCCTTAGATGATCCAAATC3'), and SWAM18SR1 (5'-ATCGTCGTTAAAGGGT TTAAAGTGTACTCATTCCAATTACGGAGC-3') for the 18S rRNA gene (PALUMBI 1996). The PCR conditions were as follows: COI - initial denaturation step of $4 \mathrm{~min}$ at $94^{\circ} \mathrm{C}$, followed by 35 cycles of $1 \mathrm{~min}$ at $94^{\circ} \mathrm{C}, 1 \mathrm{~min}$ at $55^{\circ} \mathrm{C}, 2 \mathrm{~min}$ at $72^{\circ} \mathrm{C}$, and a final extension of $4 \mathrm{~min}$ at $72^{\circ} \mathrm{C} ; 18 \mathrm{~S}$ - initial denaturation step of $4 \mathrm{~min}$ at $94^{\circ} \mathrm{C}$, followed by 40 cycles of $45 \mathrm{~s}$ at $94^{\circ} \mathrm{C}$, $45 \mathrm{~s}$ at $51^{\circ} \mathrm{C}, 2 \mathrm{~min}$ at $72^{\circ} \mathrm{C}$ and, after all cycles were completed, an additional elongation step of 4 min at $72^{\circ} \mathrm{C}$ was performed. The total volume of each PCR reaction mixture was $50 \mu \mathrm{l}$. To check the quality of the PCR products $10 \mu \mathrm{l}$ of the PCR product was ran on $1 \%$ agarose gel. The PCR products were purified using Clean-Up columns (A\&A Biotechnology) and were then amplified in both directions (HILLIS et al. 1996) using BigDye Terminator v3.1 (Applied Biosystems), following the manufacturer's protocol and with the primers described above. The sequencing reaction products were purified using ExTerminator Columns (A\&A Biotechnology); DNA sequences then underwent electrophoresis on an ABI Prism sequencer. The two sequences were deposited in GenBank (Table 1).

In the phylogeny reconstruction, we used 28 rissooid taxa sequences from GenBank (Table 1). Seven of them, used as an outgroup, represented the 
Table 1. Taxa used for phylogenetic analyses, with their GenBank Accession Numbers and references

\begin{tabular}{|c|c|c|c|}
\hline Species & 18S GB\# & COI GB\# & References \\
\hline Adriohydrobia gagatinella (Küster, 1852) & AF367657 & AF317881 & WILKE \& FALNIOWSKI (2001) \\
\hline Adrioinsulana conovula (Frauenfeld, 1863) & AF367656 & AF367628 & WILKE et al. (2001) \\
\hline Agrafia wiktori Szarowska et Falniowski, 2011 & JF906758 & JF906762 & SZAROWSKA \& FALNIOWSKI (2011a) \\
\hline Alzoniella finalina Giusti et Bodon, 1984 & AF367686 & AF367650 & WILKE et al. (2001) \\
\hline Anagastina zetavalis (Radoman, 1973) & EF070622 & EF070616 & SZAROWSKA (2006) \\
\hline Bithynia tentaculata (Linnaeus, 1758) & AF367675 & AF367643 & WILKE et al. (2001) \\
\hline Boleana umbilicata (Kuščer, 1932) & JX982797 & JX982795 & FALNIOWSKI \& SZAROWSKA (2012) \\
\hline Bythinella austriaca (Frauenfeld, 1857) & AF212917 & FJ545132 & FALNIOWSKI et al. (2009) \\
\hline Bythiospeum sp. & AF367664 & AF367634 & WILKE et al. (2001) \\
\hline Dalmatinella fluviatilis Radoman, 1973 & KC344539 & KC344541 & FALNIOWSKI \& SZAROWSKA (2013) \\
\hline Daphniola graeca Radoman, 1973 & EF070624 & EF070618 & SZAROWSKA (2006) \\
\hline Dianella thiesseana (Kobelt, 1878) & AY676125 & AY676127 & SZAROWSKA et al. (2005) \\
\hline $\begin{array}{l}\text { Graecoarganiella parnassiana Falniowski } \\
\quad \text { et Szarowska, } 2011\end{array}$ & JN202341 & JN202348 & FALNIOWSKI \& SZAROWSKA (2011) \\
\hline Graziana alpestris (Frauenfeld, 1863) & AF367673 & AF367641 & WILKE et al. (2001) \\
\hline Grossuana codreanui (Grossu, 1946) & EF061916 & EF061919 & SZAROWSKA et al. (2007) \\
\hline Hauffenia tellinii (Pollonera, 1898) & AF367672 & AF367640 & WILKE et al. (2001) \\
\hline Heleobia dalmatica (Radoman, 1974) & AF367661 & AF367631 & WILKE et al. (2001) \\
\hline Hydrobia acuta (Draparnaud, 1805) & AF367680 & AF278808 & WILKE \& DAVIS (2000) \\
\hline Islamia piristoma Bodon et Cianfanelli, 2001 & AF367671 & AF367639 & WILKE et al. (2001) \\
\hline Lithoglyphus naticoides (C. Pfeiffer, 1828) & AF367674 & AF367642 & WILKE et al. (2001) \\
\hline Marstoniopsis insubrica (Küster, 1853) & AF367676 & AY027813 & FALNIOWSKI \& WILKE (2001) \\
\hline Pseudamnicola lucensis (Issel, 1866) & AF367687 & AF367651 & WILKE et al. (2001) \\
\hline Pyrgula annulata (Linnaeus, 1767) & AY676124 & AY341258 & SZAROWSKA et al. (2005) \\
\hline Radomaniola callosa (Paulucci, 1881) & AF367685 & AF367649 & WILKE et al. (2001) \\
\hline Rissoa labiosa (Montagu, 1803) & AY676126 & AY676128 & SZAROWSKA et al. (2005) \\
\hline Sadleriana fluminensis (Küster, 1853) & AF367683 & AY273996 & WILKE et al. (2001) \\
\hline Trichonia kephalovrissonia Radoman, 1973 & EF070630 & EF070619 & SZAROWSKA (2006) \\
\hline Ventrosia ventrosa (Montagu, 1803) & AF367681 & AF118335 & WILKE \& DAVIS (2000) \\
\hline Vinodolia fiumana Radoman, 1973 & KF359899 & KF359900 & present study \\
\hline
\end{tabular}

main non-hydrobiid lineages within the Rissooidea (WILKE et al. 2001); the other seven taxa represented the Hydrobiinae (including "Pyrgulinae": SZAROWSKA et al. 2005). The remaining taxa were chosen to represent all the main lineages within the European Sadlerianinae (SZAROWSKA 2006).

The COI sequences were aligned by eye using BioEdit 5.0.0 (HALL 1999) and edited with MACCLADE 4.05 (MADDISON \& MADDISON 2002). For 18S, an initial alignment was performed using CLUSTALX 1.82 (THOMPSON et al. 1997) and edited with MACCLADE. Mutational saturation for the COI dataset was examined by plotting the numbers of transitions and transversions for all the codon positions together, and for the 3rd position separately, against the percentage sequence divergence, using DAMBE 5.2 .9 (XIA 2000). We also used DAMBE 5.2.9 to per- form the saturation test (XIA et al. 2003). It revealed a significant degree of saturation in the third position of the sequences. In rissooids, COI approaches saturation with about $18.6 \%$ or 120 nucleotide differences (DAVIS et al. 1998), which seems to happen after approximately 10 million years. However, to avoid a substantial loss of information in the case of closely related species, this position was not excluded from the dataset and it was used for the analysis. In fact, the analysis carried out on the 2nd and 3rd position only resulted in similar deep phylogeny, but with several polytomies within more terminal nodes.

Initially, we performed phylogeny reconstruction for $18 \mathrm{~S}$ and COI data separately, using the maximum likelihood (ML) technique. Next, the partition homogeneity test (FARRIS et al. 1995) was performed (1,000 replicates) with PAUP*4.0b10 (SWOFFORD 2002), to 


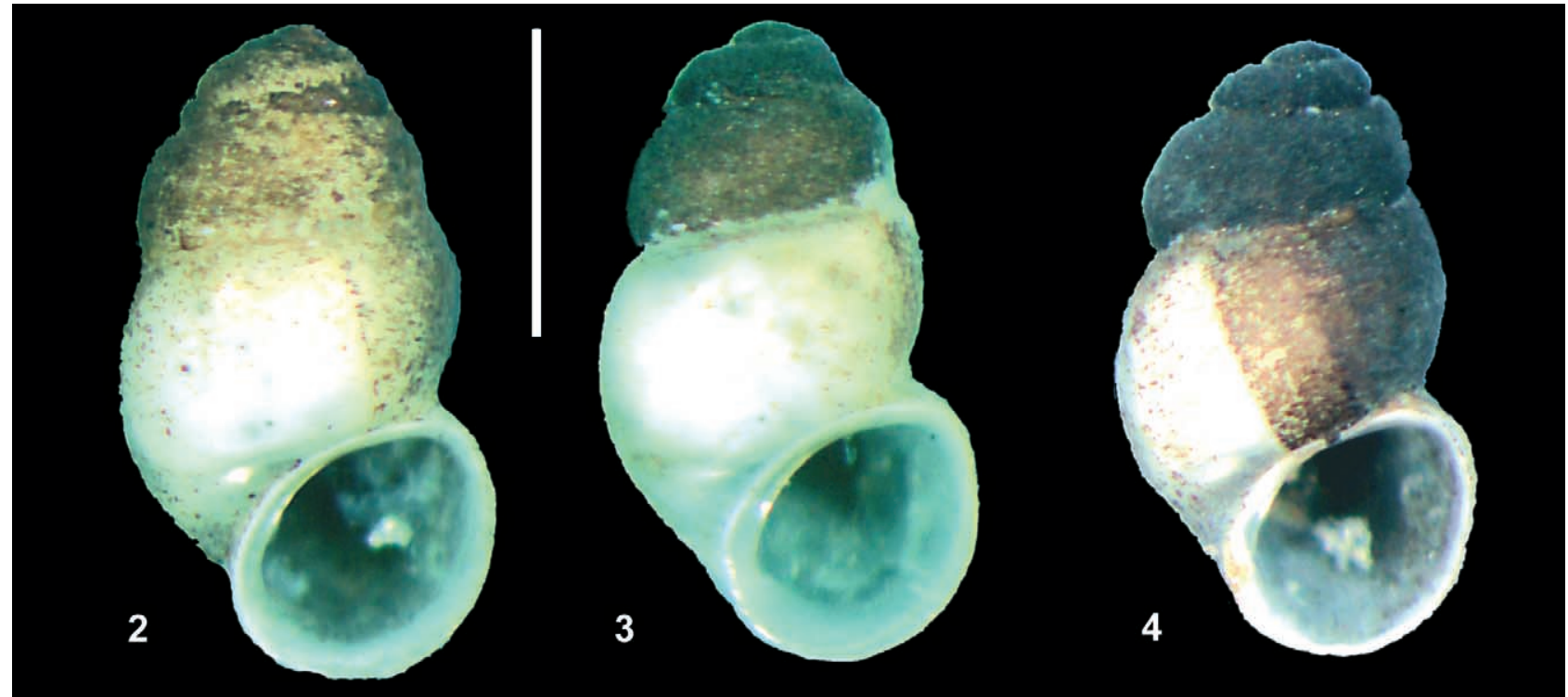

Figs 2-4. Shells of Vinodolia fiumana: 2-3 - female, 4 - male; scale bar equals $1 \mathrm{~mm}$
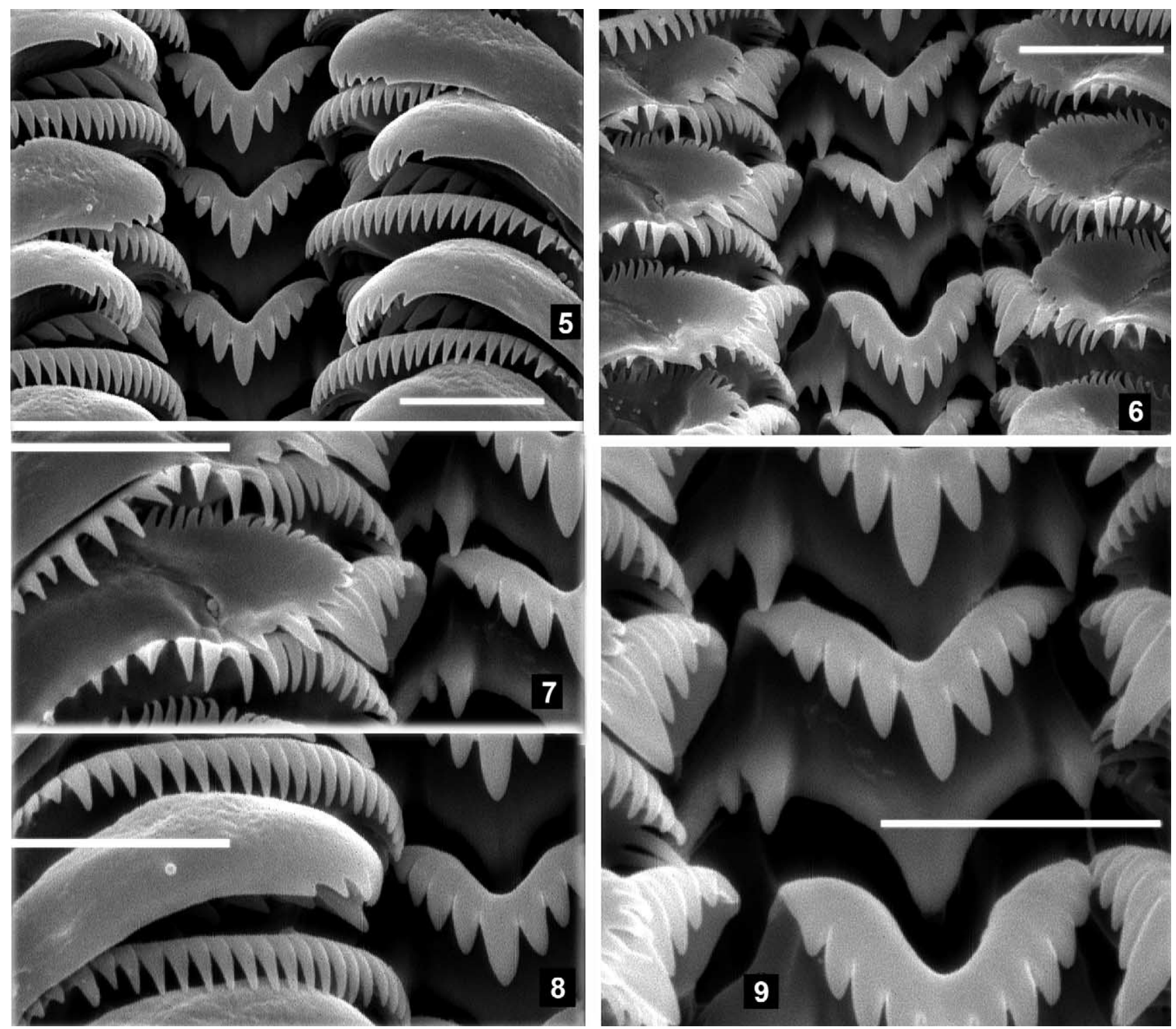

Figs 5-9. Radula of Vinodolia fiumana, scale bars equal $5 \mu \mathrm{m}$ 
check whether the two genes could be analysed together. Since $\mathrm{p}>0.723$, the maximum likelihood heuristic search was then run for the combined molecular data. Following the recommendations of SOBER (2002) and POSADA \& BUCKLEY (2004), the best model for each dataset was chosen using the Akaike Information Criterion (AIC) and Bayesian Information Criterion (BIC); both chose the same model. We performed ML analyses in PAUP* and used a heuristic search strategy with stepwise addition of taxa,

\section{RESULTS AND DISCUSSION}

Shell (Figs 2-4) ovate-conical, thin-walled and translucent, with weakly marked possible dimorphism (compare Figs 2-3 - female, and 4 - male: the male only somewhat smaller). Operculum orange. Head, foot, and visceral sac unpigmented, with the exception of small, very delicate light grey spots behind the eyes. Ctenidium absent.

Radula (Figs 5-9) taenioglossate, with many cusps on each tooth; central tooth formula:

$$
\frac{4-5(6)-4-5(6)}{2-2}
$$

(sixth cusp rudimentary, if present), basal cusps prominent, all cusps long and sharp (Figs 5-6 and 9); lateral tooth (Figs 5 and 7-8) formula: 4-1-4(5), biggest cusp less than twice as long as adjacent cusps; inner marginal tooth (Figs 5-6 and 7-8) with 23-25 long, slender and sharp cusps; outer marginal tooth
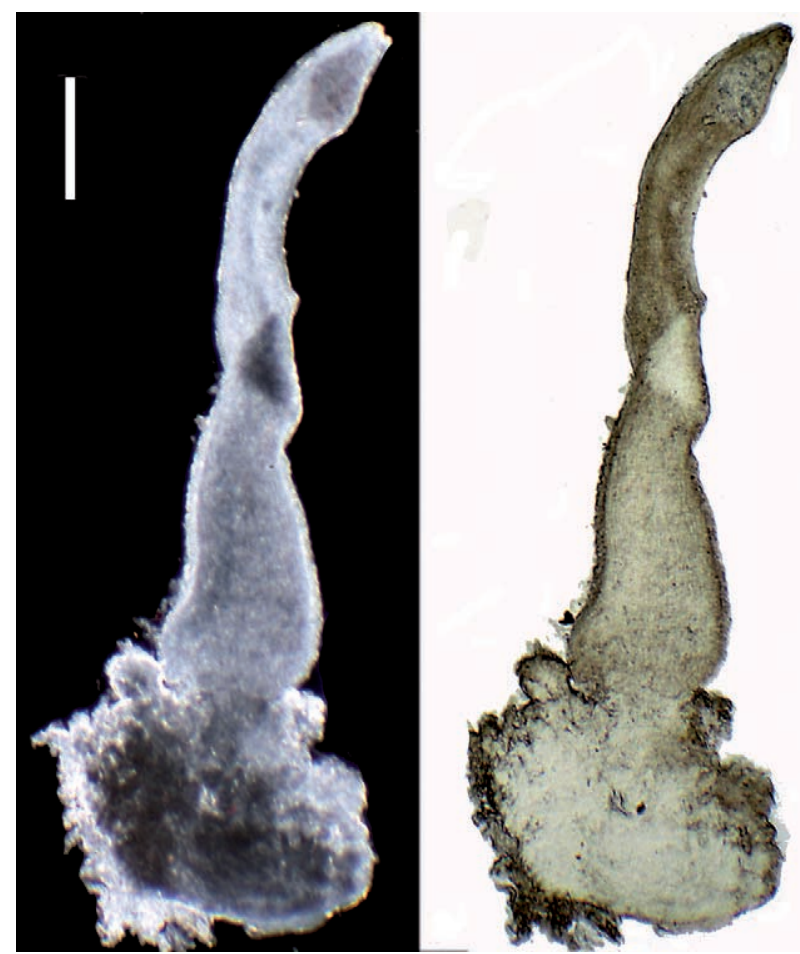

Fig. 10. Penis of Vinodolia fiumana, ventrally, scale bar equals $100 \mu \mathrm{m}$
10 random-sequence addition replicates, and treebisection-reconnection (TBR) branch swapping (SWOFFORD et al. 1996), and with MEGA5.10 (TAMURA et al. 2011). Nodal support was estimated using the bootstrap (BS) approach (FELSENSTEIN 1985). Bootstrap values for ML trees were calculated using 10,000 bootstrap replicates, with MEGA5.10 and the same model parameters as for ML analysis.

(Figs 5-7) with 24-27 cusps (small to medium-sized within a tooth).

Penis (Fig. 10) big, long and slender, terminally broadened, with slightly marked double lobe on the left side at half length, and two small lobes proximally at base, penial tip rather blunt, vas deferens visible inside terminal half.

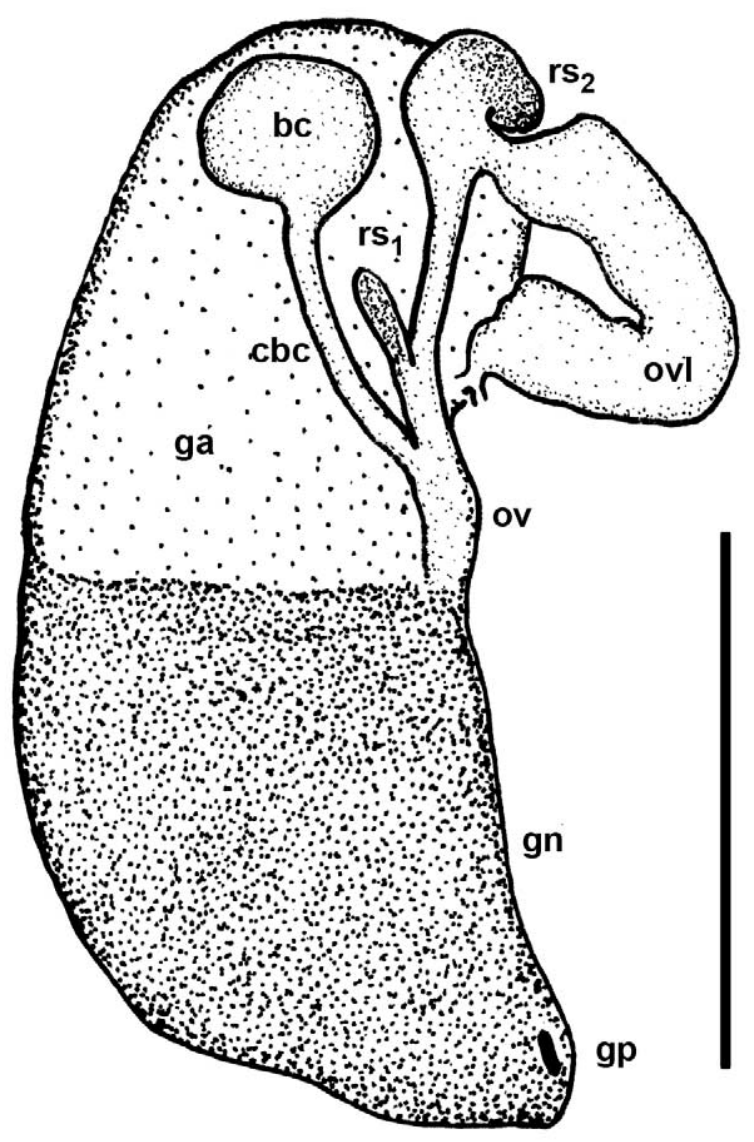

Fig. 11. Female reproductive organs of Vinodolia fiumana (bc - bursa copulatrix, cbc - duct of bursa copulatrix, ga albuminoid gland, gn - nidamental gland, gp gonoporus, ov - oviduct, ovl - loop of oviduct, $\mathrm{rs}_{1}, \mathrm{rs}_{2}-$ receptaculum seminis 1 and 2 , respectively), scale bar equals $250 \mu \mathrm{m}$ 


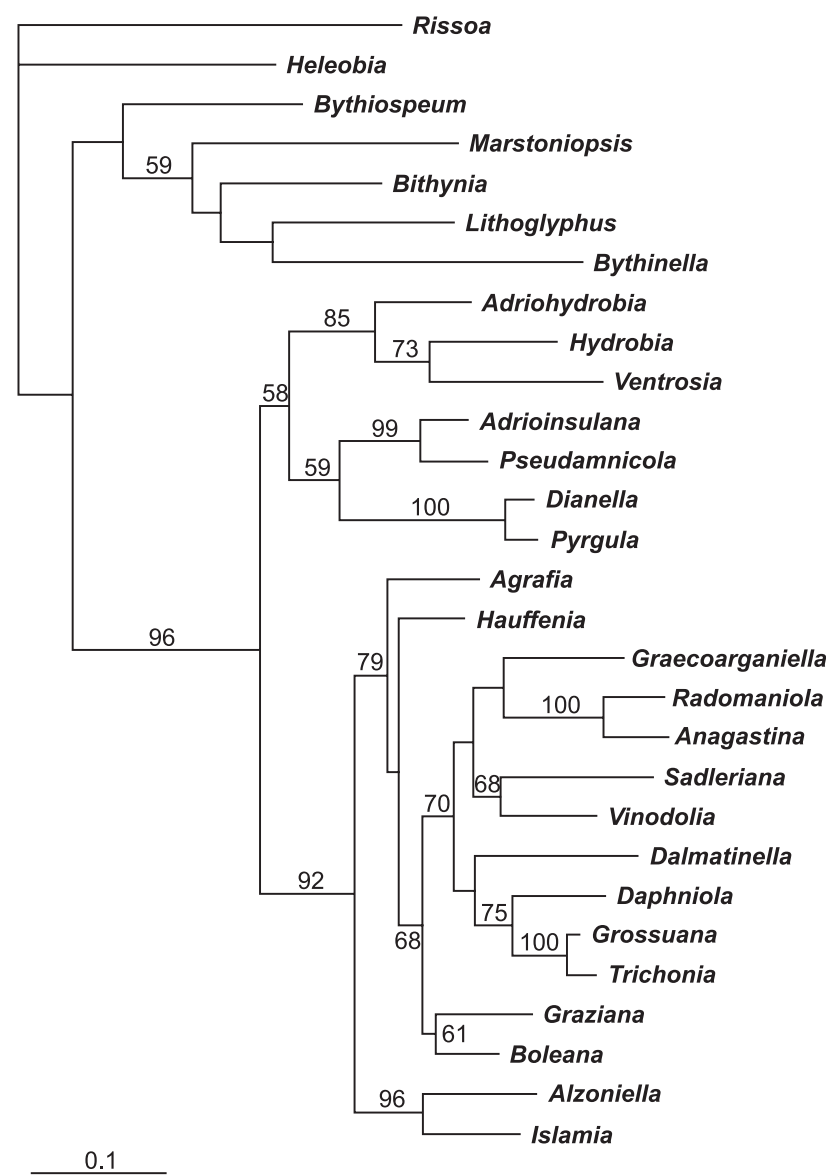

Fig. 12. Maximum likelihood tree of the two concatenated sequences (18S and COI), bootstrap supports $(10,000$ replicates) given if $>50 \%$

Female reproductive organs (Fig. 11), with two seminal receptacles, $\mathrm{rs}_{2}$ bigger than $\mathrm{rs}_{1}$, bursa copulatrix moderately big and spherical, coil of oviduct massive.

The studied V. fiumana shells are similar to the one described and figured by RADOMAN (1983: Plate III, fig. 47). This is also the case for the female genital system, which resembles the one described and drawn by RADOMAN (1973, 1974, 1983: fig. 23). This cannot be said about the penis. The penis figured by RADOMAN (1983: fig. 23) is short and broad; it is most probably contracted (due to fixation?), without basal lobes and with a bigger, proximal, double lobe. Neither the penis of Anagastina (FALNIOWSKI et al. 2012), nor the penis of Dalmatinella (FALNIOWSKI \& SZAROWSKA 2013) resemble that of Vinodolia.

For the combined data set the Bayesian Information Criterion (BIC) and corrected Akaike Information Criterion (AICc) with MEGA5 found model TN93 (Tamura-Nei) $+\mathrm{I}+\Gamma$, with base frequencies: $\mathrm{A}=$ $0.262, \mathrm{C}=0.212, \mathrm{G}=0.220, \mathrm{~T}=0.306$; substitution rate matrix: $[\mathrm{A}-\mathrm{C}]=0.030,[\mathrm{~A}-\mathrm{G}]=0.138,[\mathrm{~A}-\mathrm{T}]=0.037$, $[\mathrm{C}-\mathrm{G}]=0.031,[\mathrm{C}-\mathrm{T}]=0.245,[\mathrm{G}-\mathrm{T}]=0.043$; proportion of invariable sites: $(\mathrm{I})=0.49$, and $\Gamma$ distribution with the shape parameter $=0.33$, and transition/transversion bias $\mathrm{R}=2.49$.

In the inferred phylogeny (Fig. 12) Vinodolia is the sister taxon of Sadleriana Clessin, 1890 (bootstrap support 68), not of Dalmatinella. Surely, the support is no high and Sadleriana cannot be more than a hypothetical sister taxon of Vinodolia, but there is enough evidence that it is closely related neither with Dalmatinella nor with Anagastina. It has to be stressed, that Anagastina is the sister taxon of Radomaniola Szarowska, 2006 (bootstrap support 100). Thus it is clear that the systematics proposed by FALKNER et al. (2001), as well as BANK (2012), or PEŠIĆ \& GLÖER (2013), cannot be accepted, being contradicted by both morphological and molecular data.

Rissooid gastropods inhabiting springs are more or less troglobiontic, depending on species, and many of them could be found at the surface only as few specimens periodically washed out from the subterranean waters during the periods of intensive outflow. Thus, Vinodolia possibly has survived in subterranean waters. SZAROWSKA (2000) describes similar reappearance in a spring after a few years of absence, for Bythinella. Indeed, as long as a spring still exists, the gastropods inhabiting it may survive, but there are many totally destroyed springs in the Balkans (SZAROWSKA \& FALNIOWSKI 2004, 2011b). Thus, $V$. fiumana may still exist in the other two localities listed by RADOMAN 1973, 1974, 1983) as well.

\section{ACKNOWLEDGMENTS}

The study was supported by a grant from the National Science Centre $(2011 / 01 / \mathrm{B} / \mathrm{NZ} 8 / 01721)$ to ANDRZEJ FALNIOWSKI.

(Gastropoda: Caenogastropoda: Rissoacea). Malacologia 40: 251-266.

FALKNER G., BANK R. A., VON PROSChWITZ T. 2001. CLECOM-PROJECT: Check-list of the non-marine Molluscan species-group taxa of the states of northern, Atlantic and central Europe (CLECOM I). Heldia 4(1/2):

$1-76$. dase I-based phylogenetic relationships among the Pomatiopsidae, Hydrobiidae, Rissoidae and Truncatelidae

Fauna Europaea version 2.5. Available from http:/ /www.faunaeur.org

Davis G. M., WILKE T., SPOlSkY C., QIU C.-P., QIU D.-C., XIA M.-Y, ZHANG Y, ROSENBERG G. 1998. Cytochrome oxi- 
FALNIOWSKI A. 1990. Anatomical characters and SEM structure of radula and shell in the species-level taxonomy of freshwater prosobranchs (Mollusca: Gastropoda: Prosobranchia): a comparative usefulness study. Folia Malacol. 4: 53-142.

FALNIOWSKi A., SZAROWSKA M. 2011. A new genus and new species of valvatiform hydrobiid (Rissooidea; Caenogastropoda) from Greece. Moll. Res. 31: 189-199.

FALNIOWSKI A., SZAROWSKA M. 2012. Phylogenetic position of Boleana umbilicata (Kuščer, 1932) (Caenogastropoda: Rissooidea). Folia Malacol. 20: 265-270. http://dx.doi. org/10.2478/v10125-012-0022-2

FALNiOWSKi A., SZAROWSKA M. 2013. Phylogenetic relationships of Dalmatinella fluviatilis Radoman, 1973 (Caenogastropoda: Rissooidea). Folia Malacol. 21: 1-7. http://dx.doi.org/10.12657/folmal.021.001

FALniowski A., SZAROWSKa M., GlÖER P., PEŠIĆ V. 2012. Molecules vs morphology in the taxonomy of the Radomaniola/Grossuana group of Balkan Rissooidea (Mollusca: Caenogastropoda). J. Conch. 41: 19-36.

FALNIOWSKI A., WiLKE T. 2001. The genus Marstoniopsis (Gastropoda: Rissooidea): intra- and intergeneric phylogenetic relationships. J. Moll. Stud. 67: 483-488. http:/ /dx.doi.org/10.1093/mollus/67.4.483

FALNiOWSKi A., SZAROWSKA M., SiRBU I. 2009. Bythinella Moquin-Tandon, 1856 (Gastropoda: Rissooidea: Bythinellidae) in Romania: species richness in a glacial refugium. J. Nat. Hist. 43: 2955-2973. http://dx.doi. org $/ 10.1080 / 00222930903359636$

FArris J. S., Källersjö M., Kluge A. G., Bult C. 1995. Testing significance of incongruence. Cladistics 10: 315-319. http://dx.doi.org/10.1111/j.1096-0031. 1994.tb00181.x

FELSENSTEIN J. 1985. Confidence limits on phylogenies: an approach using the bootstrap. Evolution 39: 783-791. http://dx.doi.org/10.2307/2408678

FOlmer O., Black M., HOEH W., Lutz R. A., VRIJENHOEK R. C. 1994. DNA primers for amplification of mitochondrial cytochrome $\mathrm{c}$ oxidase subunit I from diverse metazoan invertebrates. Mol. Mar. Biol. Biotechnol. 3: 294-299.

HALL T. A. 1999. BioEdit: a user-friendly biological sequence alignment editor and analysis program for Windows 95/98/NT. Nucleic Acids Symp. Ser. 41: 95-98.

Hillis D. M., MABle B. K., LARSON A., DAVIS S. K., ZimMER E. A. 1996. Nucleic acids IV: sequencing and cloning. In: Hillis D. M., MORITZ C., MABLE B. K. (eds). Molecular systematics. 2 ed. Sinauer Associates, Inc., Sunderland, Massachusetts, pp. 321-381.

MADDISON D. R., MADDISON W. P. 2002. MACCLADE. Ver. 4.05. [Computer software and manual]. Sinauer Associates Inc., Sunderland, Massachusetts.

Nei M., Kumar S. 2000. Molecular evolution and phylogenetics. Oxford University Press, Oxford, UK New York.

PALUMBI S. R. 1996. Nucleic acids II: the polymerase chain reaction. In: HiLlis D. M., MORITZ C., MABLE B. K. (eds). Molecular Systematics. 2 ed. Sinauer Associates Inc., Sunderland, Massachusetts, pp. 205-247.
PEŠIĆ V., GLÖER P. 2013. A new freshwater snail genus (Hydrobiidae, Gastropoda) from Montenegro, with a discussion on gastropod diversity and endemism in Skadar Lake. ZooKeys 281: 69-90. http://dx.doi.org/ 10.3897/zookeys.281.4409, www.zookeys.org

POSADA D., BUCKLEY T. R. 2004. Model selection and model averaging in phylogenetics: advantages of Akaike Information Criterion and Bayesian approaches over Likelihood Ratio Tests. Syst. Biol. 53: 793-808. http:/ /dx.doi.org/10.1080/10635150490522304

RADOMAN P. 1973. New classification of fresh and brackish water Prosobranchia from the Balkans and Asia Minor. Posebna Izdanja, Prirodn. Mus. Beograd 32: 1-30.

RADOMAN P. 1974. Dalmatinella and Vinodolia. New fresh water genera of Prosobranchia from the Yugoslav seaside. Glasnik Prirodn. Mus. Beograd ser. B 29: 41-44.

RADOMAN P. 1983. Hydrobioidea a superfamily of Prosobranchia (Gastropoda). I Systematics. Serbian Academy of Sciences and Arts, Monograph 547, Department of Sciences 57: 1-256.

RÉGnier C., Fontaine B., Bouchet PH. 2009. Not knowing, not recording, not listing: numerous unnoticed mollusk extinctions. Conserv. Biol. 23: 1214-1221. http://dx.doi. org/10.1111/j.1523-1739.2009.01245.x

SOBER E. 2002. Instrumentalism, parsimony, and the Akaike framework. Philos. Sci. 69: 112-123. http://dx.doi.org/ $10.1086 / 341839$

SWOFFORD D. L. 2002. PAUP* - Phylogenetic analysis using parsimony (*and other methods). Ver. 4. [Computer software and manual]. Sinauer Associates Inc., Sunderland, Massachusetts.

SwOFFord D. L., Olsen G. J., WAdDEll P. J., Hillis D. M. 1996. Phylogenetic Inference. In: HILLIS D. M., MORITZ C., MABle B. K. (eds), Molecular systematics. 2 ed. Sinauer Associates Inc., Sunderland, Massachusetts, pp. 407-514.

SZAROWSKA M. 2000. Environmental threats and stability of Bythinella populations in South Poland (Gastropoda: Prosobranchia: Hydrobioidea). Malak. Abh. 20: 93-986.

SZAROWSKA M. 2006. Molecular phylogeny, systematics and morphological character evolution in the Balkan Rissooidea (Caenogastropoda). Folia Malacol. 14: 99-168.

SZAROWSKA M., FALNIOWSKI A. 2004. "Hydrobioid" localities in Greece: an urgent case for conservation. Tentacle 12: $14-15$.

SZAROWSKA M., FALNIOWSKI A. 2011a. An unusual, flagellum-bearing hydrobiid snail (Gastropoda: Rissooidea: Hydrobiidae) from Greece, with descriptions of a new genus and a new species. J. Nat. Hist. 45: 2231-2246. http:/ /dx.doi.org/10.1080/00222933.2011.591067

SZAROWSKA M., FALNIOWSKI A. 2011b. Destroyed and threatened localities of rissooid snails (Gastropoda: Rissooidea) in Greece. Folia Malacol. 19: 35-39. http://dx.doi.org/10.2478/v10125-011-0010-y

SZAROWSKA M., FALNIOWSKI A., RIEDEL F., Wilke T. 2005. Phylogenetic relationships of the subfamily Pyrgulinae (Gastropoda: Caenogastropoda: Hydrobiidae) with emphasis on the genus Dianella Gude, 1913. Zootaxa 891: $1-32$. 
SZARowska M., GrZmil P., FALNiOWSKi A., SiRbU I. 2007. Grossuana codreanui (Grossu, 1946) and the phylogenetic relationships of the East Balkan genus Grossuana (Radoman, 1973) (Gastropoda: Rissooidea). Hydrobiologia 579: 379-391. http://dx.doi.org/ $10.1007 / \mathrm{s} 10750-006-0530-4$

tamura K., Peterson D., Peterson N., Stecher G., Nei M., KUMAR S. 2011. MEGA5: Molecular evolutionary genetics analysis using maximum likelihood, evolutionary distance, and maximum parsimony method. Mol. Biol. Evol. 28: 2731-2739. http://dx.doi.org/10.1093/ molbev/msr121

Thompson J. D., Gibson T. J., Plewniak F., JeAnMougin F., HigGins D. G. 1997. The ClustalX windows interface: flexible strategies for multiple sequence alignment aided by quality analysis tools. Nucleic Acids Res. 24: 4876-4882. http://dx.doi.org/10.1093/nar/25.24.4876

WILKE T., DAVIS G. M. 2000. Infraspecific mitochondrial sequence diversity in Hydrobia ulvae and Hydrobia ventrosa (Hydrobiidae: Rissoacea: Gastropoda): Do their different life histories affect biogeographic patterns and gene flow? Biol. J. Linn. Soc. 70: 89-105. http://dx.doi.org/ 10.1111/j.1095-8312.2000.tb00202.x
WiLKE T., DAVIS G. M., FALNIOWSKI A., GIUSTI F., BODON M., SZAROWSKA M. 2001. Molecular systematics of Hydrobiidae (Gastropoda: Rissooidea): testing monophyly and phylogenetic relationships. Proc. Acad. Nat. Sci. Philadelphia 151: 1-21. http://dx.doi.org/10.1635/ 0097-3157(2001)151 [0001:MSOHMG]2.0.CO;2

Wilke T., FALniowski A. 2001. The genus Adriohydrobia (Hydrobiidae: Gastropoda): polytypic species or polymorphic populations? J. Zool. Sys. Evol. Res. 39: 227-234. http://dx.doi.org/10.1046/j.1439-0469. 2001.00171.x

XIA X. 2000. Data analysis in molecular biology and evolution. Kluwer Academic Publishers, Boston, Dordrecht \& London.

Xia X., Xie Z., Salemi M., Chen L., WANG Y. 2003. An index of substitution saturation and its application. Mol. Phyl. Evol. 26: 1-7. http://dx.doi.org/10.1016/S1055-7903 (02) 00326-3

Received: March 18th, 2013

Revised: May 20th, 2013

Accepted: May 27th, 2013 